\title{
Playful Educational Intervention for Improvement of Oral Health in Children with Hearing Impairment
}

\author{
Beatriz X Ávila-Curiel ${ }^{1}$, Carlos J Solórzano-Mata ${ }^{2}$, José A Avendaño-Martínez ${ }^{3}$, Briceida Luna-Vásquez ${ }^{4}$, Rafael Torres-Rosas ${ }^{5}$
}

\begin{abstract}
Dental care to vulnerable population is a pending issue in health policies due to the lack of appropriate and specialized strategies. Children with sensory deficits represent a challenge to professionals in prevention of oral diseases fundamentally due to communication problems. Aims and Objectives: This study was conducted to compare the simplified oral hygiene index (OHI-S) before and after a playful learning intervention in children with hearing impairment between 6 years and 11 years.

Study design: Educational strategies were adopted for children with hearing impairment in Mexican Sign Language. The intervention consisted of three meetings explaining topics and activities of preventive content on health and oral hygiene for the children and their tutors. Simplified oral hygiene index was determinate before and after intervention.

Results: The mean of OHI-S score was $12 \%$ good status before the intervention and $64 \%$ after the application of the educational strategy.

Conclusion: Teachers and dentists can enhance oral health promotion actions to children with hearing impairment in elementary institution using playful learning interventions.

Keywords: Hearing impairment, Playful educational intervention, Simplified oral hygiene index.

International Journal of Clinical Pediatric Dentistry (2019): 10.5005/jp-journals-10005-1701
\end{abstract}

\section{INTRODUCTION}

Education in oral health is the key to prevention of oral diseases. ${ }^{1}$ The health of children is determined by multiple interactions with the environment; however, such interactions can be affected if it is perceived in a distorted way. These influences can be divided into biological, behavioral, physical, social, and educational environment. ${ }^{2-5}$ In educational oral healthcare, the hearing-impaired has special accessibility problems due the lack of information made for their special needs for communication, and the children have also more difficulties due the pedagogical requirements. The healthcare staff is not so aware of the issues that deaf children face due to their communication skills problems. ${ }^{6-9}$

The World Health Organization supported the promotion of oral health, in 1989, as an integral part of health actions for all, and the Fifth International Conference on Health Promotion was carried out in Mexico City with the central theme "Bridging the equity gap".10,11 During Mexico Day, the session was dedicated to showcasing a range of Mexican experiences of health promotion as a crosscutting approach applied to disease prevention. However, there is no topic for patients with hearing-impaired discussed at the session. That is, equality for persons with disabilities sometimes is forgotten.

The aim of this research focuses in the study of oral health status in deaf children and compares the simplified oral hygiene index (OHI-S) before and after a playful learning intervention and builds a collective awareness of the importance to implement pedagogical tolls in the schools and dentist's offices.

\section{Materials and Methods}

\section{Subjects}

This study was approved by the local Ethics Committee as 16POC003FO. All volunteers enrolled were scholar deaf children between 6 years and 11 years from the "Centro Oaxaqueño CORAL A.C". All tutors provided written informed consent and interventions
1,2,4,5 Department of Odontology, Facultad de Odontología, Universidad Autónoma Benito Juárez de Oaxaca, Oaxaca, Mexico

${ }^{3}$ Department of Odontology, Facultad de Odontología, Universidad Autónoma Benito Juárez de Oaxaca, Oaxaca, Mexico; Department of Psychology, Universidad Autónoma Benito Juárez de Oaxaca, Oaxaca, Mexico

Corresponding Author: Rafael Torres-Rosas, Department of Odontology, Facultad de Odontología, Universidad Autónoma Benito Juárez de Oaxaca, Oaxaca, Mexico, Phone: +52 951502 0700, e-mail:drtorres1981@ hotmail.com

How to cite this article: Ávila-Curiel BX, Solórzano-Mata CJ, AvendañoMartínez JA, et al. Playful Educational Intervention for Improvement of Oral Health in Children with Hearing Impairment. Int J Clin Pediatr Dent 2019;12(6):491-493.

Source of support: PFCE 2016-2017

Conflict of interest: None

were in accordance with the Declaration of Helsinki, including current revisions, Good Clinical Practice guidelines, and Ethics Operations Manual in research.

\section{Study Protocol}

The playful learning intervention consisted of three sessions for instructing deaf children to improve the toothbrushing technique. The sessions (lasted approximately 120 minutes) were consecutive with an interval of 3 days between each of them and conducted by a researcher in the "Centro Oaxaqueño CORAL A.C", which is an educational institution. A game named "Loti-denti" was assessed with dental pictures creating a lottery game of them. The deck is composed of a set of 45 different dental and oral health images, each one in a card. In the game, the caller randomly chooses a card from the deck and says it to the players by its name. The players with a matching image on their board 
Playful Educational Intervention for Improvement of Oral Health in Children with Hearing Impairment

mark it off with a candy, and the first player fills the board jump and is the winner. After that, a presentation of oral health with the images and Mexican Sign Language was performed, and also a letters soup game and coloring book were used for the playful learning intervention.

\section{Simplified Oral Hygiene Index}

Simplified plaque index and simplified calculus index were evaluated accordingly to Greene and Vermillion's index. The technique was calibrated by intraobservers, which scored and registered the amount of plaque on the teeth through a four-point scale: $0=$ there is no presence of stain due to no plaque on the teeth; 1 = dental plaque stained that covering no more than the cervical-third of the clinical crown; $2=$ dental plaque stained that covering more than the cervical-third but no more than middlethird of the of the clinical crown; and $3=$ dental plaque stained that covering more than the middle-third of the clinical crown. The amount of calculus on teeth was recorded employing a four-point scale $(0=$ there is no presence of calculus; $1=$ supragingival calculus covering not more than the cervical-third of the clinical crown; 2 = supragingival calculus covering more than the cervical-third but not more than the middle-third of the clinical crown or the presence of single spots of subgingival calculus around the cervical line of the anatomical crown or both; 3 = supragingival calculus covering more than the middle-third of the clinical crown or a continuous heavy band of subgingival calculus around the cervical line of the anatomical crown or both). The final score for both scales results in a categorization as good, regular, and deficient oral hygiene status, in accordance with the OHI-S. ${ }^{12,13}$

\section{Oral Health Status}

The decayed, missing, and filled teeth (dmft) index for children was performed as it was previously described. ${ }^{14}$

\section{Statistical Analysis}

All tests were performed using the GraphPad Prism Software (GraphPad Software, La Jolla, CA). All data were expressed at the figures and text as percentages. Statistical analysis was performed using Chi-square; $p$ values $\leq 0.05$ were considered statistically significant.

\section{Results}

An evaluation of the 25 participants was performed, corresponding to 399 deciduous and 133 permanent teeth. In this evaluation, 78\% of the teeth were free of fractures, enamel infractions, and any dental abnormality. $17.5 \%$ of the teeth presented dental caries, $0.8 \%$ were free of carious lesions, $0.4 \%$ had a restoration not related to caries, and 3.4\% had a dental prosthodontics (Table 1).

$\mathrm{OHI}-\mathrm{S}$ score was measured before and after the playful learning intervention. At the beginning, the OHI-S was deficient in $44 \%$, regular in $44 \%$, and good in $12 \%$ of the participants, and as the result from a repeated playful education, the $\mathrm{OHI}-\mathrm{S}$ was $0 \%$ deficient, $36 \%$ regular, and $64 \%$ good (Fig. 1).

\section{Discussion}

The children's OHI-S improved after the learning intervention using playful. Those results are in accordance with the report of Nazri et al. They affirm that the education with visual information such as cartoons about the correct way to brush the teeth could lead to children with hearing impairment to have a good brushing habit,
Table 1: Results of evaluation of oral health status

\begin{tabular}{lllll}
\hline Status & & Primary & Permanent & Total \\
\hline Sound & $n$ & 293 & 122 & 415 \\
& $(\%)$ & 73.4 & 91.7 & 78.0 \\
Decayed & $n$ & 82 & 11 & 93 \\
Filled no decay & $(\%)$ & 20.6 & 8.3 & 17.5 \\
& $n$ & 4 & 0 & 4 \\
Fissure sealant & $(\%)$ & 1.0 & 0.0 & 0.8 \\
& $n$ & 2 & 0 & 2 \\
Bridge abutment, special & $n$ & 0.5 & 0.0 & 0.4 \\
crown, or veneer/implant & & 18 & 0 & 18 \\
& $(\%)$ & 4.5 & 0.0 & 3.4 \\
Total & $n$ & 399 & 133 & 532 \\
& $(\%)$ & 100 & 100 & 100 \\
\hline
\end{tabular}

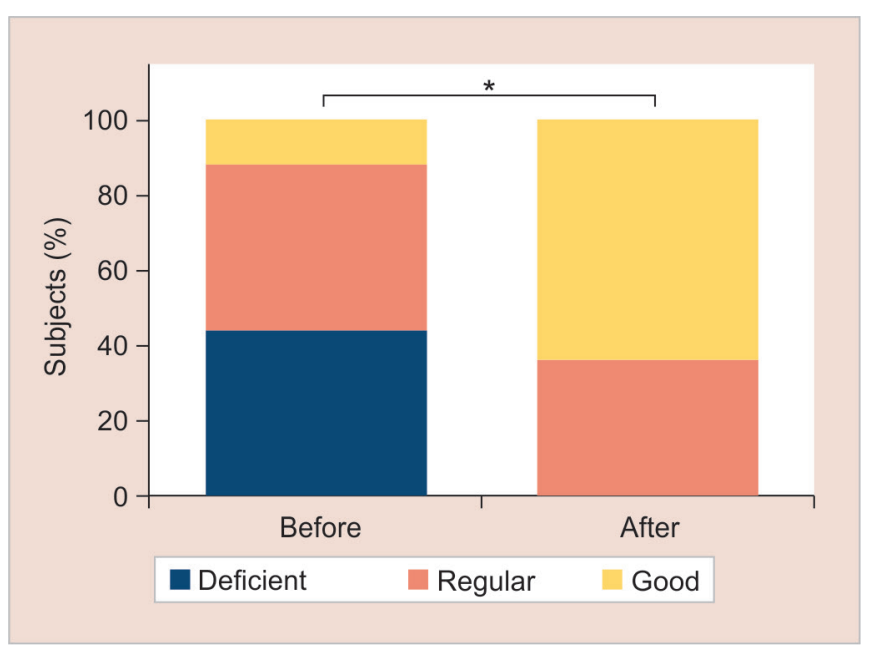

Fig. 1: Simplified oral hygiene score before and after the playful learning intervention. ${ }^{*} p>0.0001$

as well as to improve knowledge of dental hygiene and decrease the OHI-S score. ${ }^{15}$ The game is a way for children to learn and discover the world, promoting creativity and imagination, and spontaneous learning requires the experience to be fun, which can increase the participation of children. In addition, the playful is also a good tool for a holistic approach to knowledge development. Therefore, it is very important to use dental health education methods for children with hearing impairment, who tend to use the other senses to receive information. The use of the game as a tool to transmit messages in the subconscious can provide a positive influence on motivation toward healthy behavior and good dental habits. ${ }^{16}$

Doichinova and Peneva also report improvement of OHI-S after a motivational training program. ${ }^{17}$ The game may also work as a motivational tool for learning and formation of healthy habits. This method can change their oral health profile at a later stage of their life since the increased awareness of the dental needs results in an improved oral health status ${ }^{18-21}$ and the quality of teeth and gums. Oral health affects speaking, chewing, and swallowing; those tissues are important for communication, confidence, and nutrition. The preservation of stomatognathic tissues will influence morbidity, mortality, and quality of life of all children and especially at children with some impairment. 


\section{Conclusion}

The created playful educational intervention for deaf children improves the oral health.

\section{ACKnOWLedgments}

The authors thank volunteers, tutors, and institutions who gave their time to participate in the study. This study was supported by the Strengthening Program in Educational Quality 2016-2017 (PFCE) Grant from Secretary of Public Education (SEP), Rafael TorresRosas thank to Liliana Argueta Figueroa for her suggestions.

\section{References}

1. Nakre PD, Harikiran AG. Effectiveness of oral health education programs: A systematic review. J Int Soc Prev Community Dent 2013;3(2):103-115. DOI: 10.4103/2231-0762.127810.

2. Stein C, Santos NML, Hilgert JB, et al. Effectiveness of oral health education on oral hygiene and dental caries in schoolchildren: Systematic review and meta-analysis. Br Dent J 2018;224(5):357. DOI: 10.1038/sj.bdj.2018.195.

3. Habbu SG, Krishnappa P. Effectiveness of oral health education in children - a systematic review of current evidence (2005-2011). Int Dent J 2015;65(2):57-64. DOI: 10.1111/idj.12137.

4. Vanobbergen J, Declerck D, Mwalili S, et al. The effectiveness of a 6-year oral health education programme for Primary schoolchildren. Community Dent Oral Epidemiol 2004;32(3):173-182. DOI: 10.1111/j.1600-0528.2004.00151.x.

5. Mackie P, Sim F. Improving the health of children and young people: the world health organization global schools health initiative twenty-three years On. Public Health 2018;159:A1-A3. DOI: 10.1016/ j.puhe.2018.05.012.

6. Williams CL. Preschool teachers' theoretical and pedagogical stances on the language and literacy development of deaf and hard-of-hearing children. Implications for teacher preparation and in-service programs. Am Ann Deaf 1995;140(1):56-64. DOI: 10.1353/ aad.2012.0338.

7. Abbasi M, Eslami S, Mohammadi M, et al. The pedagogical effect of a health education application for deaf and hard of hearing students in elementary schools. Electron Physician 2017;9(9):5199-5205. DOI: $10.19082 / 5199$.
8. Hines J. Communication problems of hearing-impaired patients. Nurs Stand 2000;14(19):33-37. DOI: 10.7748/ns2000.01.14.19.33.c2752.

9. ASLH. The prevention of communication disorders tutorial. Committee on prevention of speech, language, and hearing problems. American speech-language-hearing association. ASHA Suppl 1991;6:15-42.

10. Watt RG. Strategies and approaches in oral disease prevention and health promotion. Bull World Health Organ 2005;83(9):711-718.

11. Brundtland GH. Statement by dr Gro Harlem Brundtland, Director general WHO, to the fifth global conference on health promotion, Mexico City, 5 June 2000. Health Promot Int 2001;16(1):95-98.

12. Greene JC, Vermillion JR. The simplified oral hygiene index. J Am Dent Assoc 1964;68:7-13. DOI: 10.14219/jada.archive.1964.0034.

13. Broadbent JM, Thomson WM, Boyens JV, et al. Dental plaque and oral health during the first 32 years of life. J Am Dent Assoc 2011;142(4):415-426. DOI: 10.14219/jada.archive.2011.0197.

14. Bodecker CF. The modified dental caries index. J Am Dent Assoc 1939;26:1453-1460. DOI: 10.14219/jada.archive.1939.0279.

15. Nazri-Yanti G, Mayasari-Alamsyah R, Ella-Natassa S. Effectiveness of dental health education using cartoons video showing method on knowledge and oral hygiene of deaf children in Yayasan Karya Murni Medan. International Journal of Applied Dental Sciences 2017;3(2):86-90.

16. Sigaud CHS, Santos BRD, Costa $P$, et al. Promoting oral care in the preschool child: Effects of a playful learning intervention. Rev Bras Enferm 2017;70(3):519-525. DOI: 10.1590/0034-7167-2016-0237.

17. Doichinova L, Peneva M. Motivational training Programme for oral hygiene of deaf children. International Journal of Science and Research 2015;4(2):1124-1126.

18. Klages U, Bruckner A, Zentner A. Dental aesthetics, self-awareness, and oral health-related quality of life in young adults. Eur J Orthod 2004;26(5):507-514. DOI: 10.1093/ejo/26.5.507.

19. Goodman HS, Macek MD, Wagner ML, et al. Self-reported awareness of unrestored dental caries. Survey of the oral health status of Maryland Schoolchildren, 2000-2001. Pediatr Dent 2004;26(4):369-375.

20. Al-Otaibi M, Angmar-Mansson B. Oral hygiene habits and oral health awareness among urban saudi arabians. Oral Health Prev Dent 2004;2(4):389-396.

21. Mustafa M, Asiri FYI, AlGhannam S, et al. Extent of awareness regarding oral health and dental treatment needs among individuals with hearing and speech Impairments in saudi Arabia. J Int Soc Prev Community Dent 2018;8(1):70-76. DOI: 10.4103/jispcd.JISPCD_194_17. 